FisiPublik : Jurnal Ilmu Sosial dan Politik

https://journal.uwgm.ac.id/index.php/fisipublik

P-ISSN: 2528-2689; E-ISSN: 2540-9751

Vol 03 No 02 November 2018,

\title{
Perilaku Pemilih Milenial dalam Pemilihan Gubernur Sulawesi Selatan Tahun 2018 di Kota Makassar
}

\author{
Dewi Sagita ${ }^{1}$, Junaedi², Muhammad Randhy Akbar ${ }^{3}$, Handam ${ }^{4}$ \\ ${ }^{1234}$ Program Studi Ilmu Pemerintahan, Fakultas Ilmu Sosial dan Ilmu Politik, \\ Universitas Muhammadiyah Makassar \\ Email: dewisagita@live.com, Junaedi@unismuh.ac.id, randakbar@gmail.com \\ Handam@unismuh.ac.id
}

\begin{abstract}
Abstrak
Artikel ini membahas tentang perilaku pemilih milenial dalam pemilihan gubernur Sulawesi selatan tahun 2018 di kota Makassar. Jenis penelitian yang digunakan adalah kualitatif dengan tipe penelitian deskriptif dengan jumlah informan sebanyak 7 orang. Teknik pengumpulan data yaitu dengan melakukan observasi, wawancara dan dokumentasi. Hasil penelitian dianalisis dengan menggunakan analisis berdasarkan indikator yang diambil dari teori Gaffar tentang perilaku pemilih yaitu: Pendekatan sosiologi, pendekatan psikologi dan pendekatan pilihan rasional. Berdasarkan analisis tersebut menunjukkan bahwa perilaku pemilih milenial dalam pemilihan gubernur Sulawesi selatan tahun 2018 di kota Makassar, pada proses pemilihan umum gubernur Sulawesi selatan khususnya di kota Makassar perilaku pemilih milenial dalam menentuukan pilihannya lebih dominan pada pilihan rasional dengan pertimbangan kinerja dan program kerja yang ditawarkan, walapuntidak dapat dipungkiri bahwa pendekatan sosiologi dan pendekatan psikologi tidak dapat dihilangkan dalam proses pemilihan umum, yang disebabkan oleh ketidakpahaman serta sikap acuh pemilih milenial terhadap politik dan pemilu.
\end{abstract}

Kata kunci: Perilaku Pemilih, Pemilih Milenial, Pemilihan Gubernur 
FisiPublik : Jurnal Ilmu Sosial dan Politik

https://journal.uwgm.ac.id/index.php/fisipublik

P-ISSN: 2528-2689; E-ISSN: 2540-9751

Vol 03 No 02 November 2018,

\title{
Voters milenial behavior in an election year South Sulawesi Governor 2018 in the City of Makassar
}

\begin{abstract}
This article discusses the behavior of millennial voters in the election of the governor of South Sulawesi in 2018 in the city of Makassar. The type of research used is qualitative with descriptive research type with the number of informants as many as 7 (seven) people. Data collection techniques are by conducting observations, interviews and documentation. The results of the study were analyzed using analysis based on indicators taken from Gaffar's theory of voting behavior, namely: Sociological approach, psychological approach and rational choice approach. Based on the analysis shows that millennial voters' behavior in the election of the governor of South Sulawesi in 2018 in the city of Makassar, in the process of the election of the South Sulawesi governor, especially in Makassar millennial voter behavior in determining their choices was more dominant in rational choice with consideration of performance and work programs offered, though it cannot be denied that the sociological approach and psychological approach cannot be eliminated in the electoral process, which is caused by the incomprehension and ignorance of millennial voters on politics and elections.
\end{abstract}

Keywords: Voters Behavior, Millennial Voter, Governor Election 
FisiPublik : Jurnal Ilmu Sosial dan Politik

https://journal.uwgm.ac.id/index.php/fisipublik

P-ISSN: 2528-2689; E-ISSN: 2540-9751

Vol 03 No 02 November 2018,

\section{Pendahuluan}

Pemilihan umum (Pemilu) merupakan wadah untuk rakyat agar dapat mempertajam kesadaran politiknya, dengan demikian dapat menentukan pilihan politiknya berdasarkan aspirasi dan kesadarannya. Pemilihan umum kepala daerah (pemilukada) mulai dilaksanakan sejak tahun 2005 yang berlandaskan UndangUndang No. 32 tahun 2004 tentang pemerintah daerah, pemilihan kepala daerah dan wakil kepala daerah dipilih secara langsung oleh masyarakat. Pemilihan kepala daerah yang dilaksanakan sejak tahun 2005 merupakan awal dilaksanakannya demokrasi langsung di daerah.

Menyelenggarakan sebuah proses pemilihan umum secara langsung, jujur dan adil diperlukan komitmen semua stakeholders untuk menyelenggarakan pemilihan secara transparan akuntabel. Komitmen ini harus ditunjukkan oleh semua stakeholders yang terkait seperti penyelenggara pemilu seperti KPU dan jajarannya, panwaslu, partai politik yang mengusung pasangan calon, pasangan calon, tim sukses, tim kampanye, organisasi pemantau pemilu, lembaga-lembaga pengamat serta dukungan dari masyarakat (Lumolos Jhony, 2010). Salah satu hal yang memengaruhi dalam pemilihan calon kepala daerah dalam pemilukada adalah perilaku pemilih. Perilaku politik seseorang dalam menyikapi pilkada bisa berbeda-beda satu dengan yang lain. Secara teoritis perilaku pemilih berdasarkan teori gaffar terdiri dari tiga pendekatan yaitu, pendekatan sosiologis, pendekatan psikologis dan pilihan rasional.

Pemilihan umum juga tidak bisa lepas dari keterlibatan pemilih milenial dalam menyukseskan pemilu, pemilih millenial yang dimaksud adalah pemilih generasi yang lahir pada era 90an yang identik dengan karakter berani, inovatif, kreatif, dan modern. Generasi milenial merupakan generasi modern yang aktif bekerja, penelitian, dan berpikir inovatif tentang organisasi, memiliki rasa optimisme dan kemauan untuk bekerja dengan kompetitif, terbuka, dan fleksibel serta masih memiliki jiwa nasionalisme dan paham tentang politik yang benar dan politik yang salah.

Pemilih milenial di Indonesia mampu memberikan kontribusi besar dalam politik Indonesia. Hal ini menjadikan banyak partai politik mencari tahu mengenai 
FisiPublik : Jurnal Ilmu Sosial dan Politik

https://journal.uwgm.ac.id/index.php/fisipublik

P-ISSN: 2528-2689; E-ISSN: 2540-9751

Vol 03 No 02 November 2018,

kriteria yang akan menjadi tolak ukur pemilih milenial dalam memutuskan siapa yang akan dipilih terutama pada saat proses pemilihan umum. Maka dari itu keputusan generasi milenial dalam menentukan pilihannya pada saat proses pemilihan umum berlangsung berpengaruh penting pada pemilu mendatang, dan dalam pengambilan keputusan tersebut terdapat faktor-faktor yang melatarbelakangi keputusan generasi milenial dalam memilih, antara lain voting behavior, political branding dan political disaffection (Azis, 2018).

Biasanya pemilih millenial masih dipengaruhi oleh kepentingankepentingan tertentu terutama oleh orang terdekat seperti angota keluarga, mulai dari orang tua hingga kerabat sehingga pemilih millenial merupakan sasaran yang tepat dari partai politik dalam memperoleh suara. kurangnya pendidikan politik yang mereka dapatkan serta terpengaruh dengan adanya teknologi yang memuat berbagai macam informasi mengenail pemilu.

Pemilihan umum gubernur dan wakil gubernur Sulawesi selatan merupakan ajang demokrasi politik di Indonesia. Salah satu hal yang penting dalam pelaksanan pemilihan gubernur (Pilgub) adalah perilaku pemilih yang mendukung suksesnya pemilu. perilaku politik pemilih dan partisipasi politik pemilih merupakan aspek penting yang tidak dapat dipisahkan yang merupakan aspek penunjang keberhasilan suatu pemilihan umum. Partisipasi politik masyarakat sendiri bisa saja mempengaruhi apa yang menjadi pilihan politik individu atau masyarakat itu sendiri.

Latar belakang pemilih juga mempengaruhi segala pendekatan-pendekatan terhadap pemilih. Namun pendekatan terhadap pemilih tersebut sangat dipengaruhi oleh media dan sosialisasi politik. Berdasarkan data dari Badan Pusat Statistik (BPS) pemilih millenial pada Pilkada 2018 sekitar 35\% dari keseluruhan daftar pemilih tatap (rumah pemilu.org, 31 januari 2018). pemilih millenial sebagai generasi teknologi, Kehidupannya tidak bisa dilepaskan dari teknologi terutama internet, entertainment/hiburan sudah menjadi kebutuhan pokok bagi generasi millenial, tidak terkecuali dari adanya fenomena pemilihan umum maka para pemilih millenial akan mencari informasi pemilihan umum dari internet, kita 
FisiPublik : Jurnal Ilmu Sosial dan Politik

https://journal.uwgm.ac.id/index.php/fisipublik

P-ISSN: 2528-2689; E-ISSN: 2540-9751

Vol 03 No 02 November 2018,

semua mengetahui apapun yang ada di internet tidak dapat disaring mana yang benar dan yang salah.

Media sosial sebagai sarana generasi milenial untuk bersosialisasi terdapat berbagai macam informasi yang tidak bisa dipastikan kebenarannya, Sehingga terkadang apa yang mereka pilih tidak sesuai dengan yang diharapkan. Penelitian terkait dengan pemilih milenial juga dilakukan oleh Mohamad Faizal Azis, Elsy Rahmayani dan Fadillah Suwarno pada tahun 2018 "Studi Eksplorasi Voting Behavior, Political Branding, Political Disaffection Pada Generasi Pemilih Milenial. Dari penelitian tersebut dapat disimpulkan bahwa generasi milenial kurang tertarik dan tidak mengetahui banyak hal mengenai dunia politik. Tetapi hal tersebut tidak menyurutkan niat mereka dalam menggunakan hak suaranya pada saat proses pemilu berlangsung, dikarenakan kepedulian yang tinggi akan kemajuan negara yang lebih baik dan berharap masyarakat mendapatkan kesejahteraan.

Berdasarkan penelitian terkait pemilih milenial juga dilakukan oleh Retnayu Prasetyanti tahun 2017 “Generasi Millennial Dan Inovasi Jejaring Demokrasi Teman Ahok". Dari hasil penelitian tersebut dapat disimpulkan bahwa Generasi Millennial bukan hanya sekedar optimisme beberapa pihak, lebih jauh, pendapat ini dapat menjadi semangat baru yang dapat menggerakkan peran masyarakat terutama generasi muda untuk lebih optimis terhadap masa depan politik daerah yang merupakan implikasi dari kreativitas, semangat nasionalisme gaya baru, dan gambaran lemahnya kredibilitas aktor politik nusantara.

Penelitian tentang pemilih milenial juga dilakukan oleh Muhamad Isnaini tahun 2017 "Gerakan Kerelawanan Generasi Milenial: Kasus Pada Pemilihan Kepala Daerah (Pilkada) Jakarta 2017 Dalam Perspektif Komunikasi Politik". gerakan kerelawanan yang digagas oleh generasi muda, baik sebagai pendukung kandidat maupun sebagai pengawas jalannya pilkada. generasi milenial dengan menggagas gerakan kerelawanan merupakan indikasi kesiapan mereka sebagai aktor politik. Wujud actor politik tersebut adalah sebagai aktivis, yang menjembatani kepentingan masyarakat dengan kandidat yang mereka usung, serta untuk mencapai proses berdemokrasi yang lebih jujur, adil, dan transparan. 
FisiPublik : Jurnal Ilmu Sosial dan Politik

https://journal.uwgm.ac.id/index.php/fisipublik

P-ISSN: 2528-2689; E-ISSN: 2540-9751

Vol 03 No 02 November 2018,

Generasi milenial, melalui partisipasinya dalam politik, tidak hanya menginginkan perubahan, namun juga berharap menjadi agen perubahan dengan cara mereka sendiri.Tujuan dari artikel ini agar kita dapat menegetahui perilaku pemilih milenial dalam pemilihan gubernur Sulawesi selatah tahun 2018 di kota Makassar serta referensi pemilih milenial dalam menentukan pilihannya pada proses pemilihan umum.

\section{Metodologi}

Penelitian ini dilakukan selama 2 bulan yang dimulai dari tangal 20 oktober sampai 20 desember 2018. Adapun lokasi penelitian ini adalah kantor KPU provinsi Sulawesi selatan dan KPU kota Makassar. Jenis penelitian ini adalah kualitatif dengan tipe penelitian deskriptif. Adapun jumlah informan pada penelitian ini sebanyak 7 orang yang terdiri dari teknisi KPU provinsi Sulawesi selatan, komisioner KPU makasar, serta pemilih milenial yang berjumlah 5 orang.

\section{Hasil dan Pembahasan}

Sebelum masuk dalam pembahasan hasil penelitian mengenai perilaku pemilih milenial dalam pemilihan gubernur Sulawesi selatan tahun 2018 di kota Makassar, penulis akan memaparkan lokasi yaitu di kota Makassar, lebih tepatnya di kantor KPU Makassar. Kota Makassar merupakan salah satu pemerintahan kota dalam wilayah Provinsi Sulawesi Selatan yang terbentuk berdasarkan Undang-Undang Nomor 29 Tahun 1959 tentang Pembentukan Daerah-daerah Tingkat II di Sulawesi, sebagaimana yang tercantum dalam Lembaran Negara Republik Indonesia Tahun 1959 Nomor 74 dan Tambahan Lembaran Negara Republik Indonesia Nomor 1822. Kota Makassar menjadi ibukota Provinsi Sulawesi Selatan berdasarkan Undang-Undang Nomor 13 Tahun 1965, (Lembaran Negara Tahun 1965 Nomor 94). kemudian berdasarkan Undang-Undang Nomor 8 Tahun 1965 Daerah Tingkat II Kotapraja Makassar diubah menjadi Daerah Tingkat II Kotamadya Makassar.

Kota Makassar yang pada tanggal 31 Agustus 1971 berubah nama menjadi Ujung Pandang, wilayahnya dimekarkan dari 21 km2 menjadi 175,77 km2 dengan 
FisiPublik : Jurnal Ilmu Sosial dan Politik

https://journal.uwgm.ac.id/index.php/fisipublik

P-ISSN: 2528-2689; E-ISSN: 2540-9751

Vol 03 No 02 November 2018,

mengadopsi sebagian wilayah kabupaten lain yaitu Gowa, Maros, dan Pangkajene Kepulauan, hal ini berdasarkan Peraturan Pemerintah Nomor 51 Tahun 1971 tentang Perubahan batas-batas daerah Kotamadya Makassar dan Kabupaten Gowa, Maros dan Pangkajene dan Kepulauan, lingkup Daerah Provinsi Sulawesi Selatan. Pada perkembangan, nama Kota Makassar dikembalikan lagi berdasarkan Peraturan Pemerintah Nomor 86 Tahun 1999 tentang Perubahan Nama Kotamadya Ujung Pandang menjadi Kota Makassar, hal ini atas keinginan masyarakat yang didukung DPRD Tk. II Ujung Pandang saat itu, serta masukan dari kalangan budayawan, seniman, sejarawan, pemerhati hukum dan pelaku bisnis.

Komisi Pemilihan Umum (KPU) kota Makassar adalah lembaga negara yang menyelenggarakan pemilihan umum di Indonesia. KPU yang ada sekarang merupakan KPU keempat yang dibentuk sejak era Reformasi 1998. Undang-Undang Nomor 22 Tahun 2007 Tentang Penyelenggara Pemilu diatur mengenai KPU, KPU Provinsi, dan KPU Kabupaten/Kota sebagai lembaga penyelenggara pemilihan umum yang permanen dan Bawaslu sebagai lembaga pengawas Pemilu. KPU dalam menjalankan tugasnya bertanggung jawab sesuai dengan peraturan perundang-undangan serta dalam hal penyelenggaraan seluruh tahapan pemilihan umum dan tugas lainnya. KPU memberikan laporan Presiden kepada Dewan Perwakilan Rakyat.

Berdasarkan hasil observasi, peneliti mengobservasi 7 informan untuk dijadikan sampel. Informan yang diambil menunjukkan bahwa 4 orang berjenis kelamin perempuan dan 3 orang berjenis kelamin laki-laki. Perilaku politik pemilih milenial pada pemilihan Gubernur Sulawesi selatan tahun 2018 di kota Makassar, dapat diukur atau dianalisis menggunakan indikator berdasarkan teori dari Gaffar yaitu:

1. Pendekatan sosiologis

2. Pendekatan psikologis

3. Pilihan rasional 
FisiPublik : Jurnal Ilmu Sosial dan Politik

https://journal.uwgm.ac.id/index.php/fisipublik

P-ISSN: 2528-2689; E-ISSN: 2540-9751

Vol 03 No 02 November 2018,

\section{Pendekatan sosiologis}

Pendekatan sosiologis merupakan pendekatan yang lebih menekankan kepada faktor-faktor sosiologi yang kemudian membentuk perilaku memilih seseorang. Pendekatan ini pada dasaranya menjelaskan bahwa karakteristik dan pengelompokan sosial mempunyai pengaruh dalam menentukan perilaku memilih seseorang. Pendekatan sosiologis yang dimaksud adalah preferensi pemilih milenial dalam menetukan pilihannya dalam pemilihan umum berdasarkan karakteristik sosial ekonomi, seperti agama, profesi, kelas sosial serta peran orang tua yang bisa mempengaruhi pilihan pemilih.

Dalam proses pemilihan Gubernur Sulawesi selatan, para pemilih milenial dalam menentukan pilihannya masih ada pemilih milenial dalam menggunakan hak pilihnya masih bergantung pada orang lain yang disebabkan oleh ketidak pahaman pemilih milenial terkait politik dan pemilihan umum. Hal ini sesuai dengan teori dari Gaffar dalam Yustiningrum (2010) bahwa Perilaku memilih seseorang cenderung mengikuti arah politik lingkungan sosial dimana dia berada, serta dari berbagai ikatan sosial yang ada dimasyarakat.

Selain itu David Apter dalam Indar Melani (2014) menguraikan tentang pengaruh dari keluarga terhadap anak dalam memilih yaitu adanya kesamaan pilihan seorang anak dengan pilihan orang tuanya. Bahwa, "adanaya kesejajaran atau kesamaan pilihan antara orang tua dengan anaknya merupakan suatu yang wajar. Sebab pada lembaga keluarga itulah seseorang pertama kalai mempunyai akses pembentukan identitas diri, mempelajari nilai-nilai lingkungan dan sosial mereka, termasuk peran politiknya.

\section{Pendekatan psikologis}

Perilaku pemilih berdasarkan pendekatan psikologi sangat tergantung pada sosialisasi politik lingkungan yang menyelimuti diri pemilih. Identifikasi kepartaian sebagai wujud dari sosialisasi politik yang bisa dibina oleh orang tua, organisasi sosial kemasyarakatan dan lainnya. Sosialisasi ini berkenaan dengan nilai dan norma yang diturunkan oleh orang tua, organisasi sosial 
FisiPublik : Jurnal Ilmu Sosial dan Politik

https://journal.uwgm.ac.id/index.php/fisipublik

P-ISSN: 2528-2689; E-ISSN: 2540-9751

Vol 03 No 02 November 2018,

kemasyarakatan dan lainnya sebagai bentuk penurunan dan penanaman kepada genarasi baru. Pendekatan ini melihat faktor psikologis yang melatarbelakangi pilihan seseorang berdasarkan identifikasi partai yang mengacu pada proses pemilihan melalui nama seseorang yang merasa dekat dengan salah satu partai. Pendekatan psikologis yang dimaksud adalah preferensi pemilih milenial dalam pemilihan umum berdasarkan hubungan kedekatan dengan calon, tim sukses, atau karena faktor kedekatan dengan partai politik.

Pemilihan Gubernur di kota Makassar tahun 2018 Kepopuleran serta Kekaguman terhadap kandidat menjadi alasan pemilih milenial menjatuhkan pilihannya, mereka merasa sudah sangat mengenal sosok calon pemimpin yang dipilihnya baik itu latar belakang maupun pengalaman politik sebelumnya. Penetapan pilihan karena pemilih milenial mengidolakan kandidat tersebut sehingga, para pemilih milenial lebih mudah percaya dalam memimpin, dengan melihat pengalamannya dan adanya ikatan emosional yang ada pada dirinya karena sifat merakyat yang menurutnya pantas menjadi seorang pemimpin. Hal ini sesuai dengan teori psikologi Dieter Roth Bahwa proses pemilihan melalui identifikasi partai yaitu pemilihan yang berdasarkan pada pemilihan nama seseorang yang merasa dekat dengan salah satu partai.

\section{Pilihan rasional}

Kriteria pilihan rasional mengasumsikan bahwa seseorang yang memiliki pemahaman yang jelas mengenai apa yang ia inginkan sebagai sebuah outcome dan memiliki seperangkat kriteria yang tetap untuk mengukur alternatif yang berbeda untuk menjamin pilihannya sebagai sebuah alternatif setiap waktu.

Pilihan rasional menganggap seseorang memilih calon atau partai apabila calon atau partai tersebut dipandang dapat membantu pemilih memenuhi kepentingan dasarnya yaitu kehidupan ekonomi, oleh karena itu pendekatan ini juga disebut pendekatan ekonomis, melalui pendekatan ini, pemilih diasumsikan mempertimbangkan segala pilihan yang ada, misalnya tiap-tiap parpol yang ada, tiap-tiap kandidat yang ada dan tiap-tiap kebijakan 
FisiPublik : Jurnal Ilmu Sosial dan Politik

https://journal.uwgm.ac.id/index.php/fisipublik

P-ISSN: 2528-2689; E-ISSN: 2540-9751

Vol 03 No 02 November 2018,

yang ada. Pemilihan Gubernur Sulawesi selatan tahun 2018 khususnya di kota Makassar Pemilih milenial dalam hal ini dapat memilih secara rasional dalam menggunakan hak pilih yang diberikan dengan beberapa pertimbangan dengan melihat program-program yang dijanjikan bahkan melihat dari pengalamanpengalaman dalam berpolitik yang dilakukan sebelumnya.

Hal ini sesuai dengan teori Downs bahwa teori rasional pada dasarnya menekankan pada motivasi individu untuk memilih atau tidak dan bagaimana memilih berdasarkan kalkulasi mengenai keuntungan yang diakibatkan dari keputusan yang dipilih. Bagi pemilih pertimbangan untung dan rugi digunakan untuk membuat keputusan tentang partai atau kandidat yang dipilih terutama untuk membuat keputusan apakah ikut memilih atau tidak memilih.

\section{Kesimpulan}

Berdasarkan hasil penelitian maka dapat diperoleh kesimpulan bahwa perilaku politik pemilih milenial dalam pelaksanaan pemilihan gubernur dan wakil gubernur Sulawesi selatan tahun 2018 di kota Makassar, dengan indikator perilaku menurut Gaffar yaitu, Pendekatan sosiologis, pendekatan psikologis dan pendekatan rasional yang dapat disimpulkan bahwa, Pemilih milenial yang secara nasional di seluruh Indonesia baik tingkat nasinal, daerah/ kabupaten kota dan desa, jumlahnya mencapai 30\% dari daftar pemilih tetap termasuk di Makassar, perilaku dari para pemilih milenial ini yang hidup berbarengan dengan teknologi lebih dominan pada pendekatan pilihan rasional yang melihat program kerja yang ditawarkan dan kinerja pada pemerintahan sebelumnnya, serta kepopuleran calon di media sosial yang dijadikan para pemilih milenial sebagai referensi dalam menentukan pilihannya. Walaupun tidak dapat dipungkiri bahwa pilihan sosiologis atau pengaruh dari orang tua serta pilihan psikologis atau pilihan berdasarkan pada kedekatatan atau kepopuleran dengan calon kepala daerah juga tidak dapat dihilangkan, yang juga merupakan salah satu faktor atau pertimbangan dalam menentukan pilihan dalam proses pemilihan umum. 
FisiPublik : Jurnal Ilmu Sosial dan Politik

https://journal.uwgm.ac.id/index.php/fisipublik

P-ISSN: 2528-2689; E-ISSN: 2540-9751

Vol 03 No 02 November 2018,

\section{Daftar Pustaka}

Abdul Azis. 2018. "Pemilu 2019,Ada 352 Ribu Pemilih Milenial di Makassar".http://makassar.tribunnews.com/2018/12/18/pemilu-2019-ada352-ribu-pemilih-milenial-di-makassar. (diakses 8 januari 2018)

Azis, Mohamad Faizal. 2018. "Studi Eksplorasi Voting Behavior, Political Branding, Political Disaffection Pada Generasi Pemilih Millenial". Prosiding Konferensi Nasional Peneliti Muda Psikologi Indonesia 2018 Vol. 3, No. 1

Isnaini, Muhamad. 2017. "Gerakan Kerelawanan Generasi Milenial: Kasus Pada Pemilihan Kepala Daerah (Pilkada) Jakarta 2017 Dalam Perspektif Komunikasi Politik”. Fakultas Ilmu Komunikasi.Universitas Budi Luhur. Jakarta

Lumolos, Johny. 2010. "Sikap Pemilih Terhadap Pasangan Calon Kepala Daerah Menjelang Pilkada Langsung Di Kota Bitung”

Melani, Indar. 2014. "Perilaku Pemilih Pemula Di Kecamatan Duampanua Pada Pemilukada Kabupaten Pinrang Tahun 2013”. Program Studi Ilmu Politik. Universitas Hasanuddin. Makassar.

Prasetyanti, Retnayu. 2017. "Generasi Millennial Dan Inovasi Jejaring Demokrasi Teman Ahok”. Jurnal Polinter Prodi Ilmu Politik FISIP UTA'45 Jakarta. Vol. 3 No. 1

Rumah pemilu. 2018. "Partisipasi pilkada dan pemilih milenial". https://rumahpemilu.org/partisipasi-pilkada-dan-pemilih-milenial/ (diakses 22 november 2018)

Sugiyono. 2012. Metode Penelitian Kuantitatif Dan Kualitatif R\&D. Bandung. Alfabeta

Yustiningrum, Rr Emilia Dan Ichwanuddin, Wawan. 2015. "Partisipasi Politik Dan Perilaku Memilih Pada Pemilu”. Jurnal Penelitian Politik Volume 12 No. 1 